\title{
Continuing Education Opportunities
}

The following continuing education activities have been listed with ACRL's Continuing Education Clearinghouse. If your organization is sponsoring an activity that you think may be of interest to ACRL members, please send the pertinent details to the ACRL Office, $50 \mathrm{E}$. Huron St., Chicago, IL 60611.

\section{April}

16-June 7-Database: Nonbibliographic Online Database Services, seminars, Cuadra Associates, Inc.: schedule: April 16-Boston; April 17-New York; April 19-Philadelphia; May 3-Washington, D.C.; May 4-Pittsburgh; May 14-Seattle; May 21-Calgary, Alberta; May 23-Toronto, Ontario; June 7-Honolulu. Fee: $\$ 135$, $\$ 115$ if paid in advance.

Contact: Dr. Carlos A. Cuadra, 1523 Sixth St., Suite 12, Santa Monica, CA 90401; (213) 4510644.

25-28-Arts: "The University Library and the Arts," symposium, University of WisconsinMilwaukee Library. Fee: $\$ 55$.

Contact: Richard E. Jones, Music Librarian, University of Wisconsin-Milwaukee Library, P.O. Box 604, Milwaukee, WI 53201; (414) 963-5529.

\section{May}

29-June 15-Pacific Islands: "Pacific Islands Resource Materials," workshop, Graduate School of Library Studies, University of Hawaii, Honolulu.

Contact: Miles M. Jackson, Graduate School of Library Studies, University of Hawaii at Manoa, Honolulu, HI 96822.

\section{June}

4-15-Political Process: Institute on the library and the political process-federal, state, county, and local level. Catholic University of America, Washington, D.C. Fee: $\$ 260$.

Contact: Director of Continuing Education, The Catholic University of America, 620 Michigan Ave., NE, Washington, DC 20064; (202) 635-5256.

7-9-Information Flow: "The International Flow of Information: A Trans-Pacific Perspective," Institute, Center for the Book, Library of Congress; U.S. International Communication Agency; Graduate School of Library Studies, University of Hawaii; Makaha Inn, Honolulu. Contact: Sarah K. Vann, Graduate School of Library Studies, University of Hawaii at Manoa, Honolulu 96822.

11-15-Videodisc: National videodisc/microcomputer seminar and workshop, Department of
Instructional Media, Utah State University, Logan.

Contact: R. Kent Wood, Department of Instructional Media, Utah State University, Logan, UT 84322.

12-15-Management: Library Management Skills Institute, Office of Management Studies (OMS), Association of Research Libraries (ARL), Chicago, Illinois. Fee: $\$ 200$.

Contact: OMS, ARL, 1527 New Hampshire Ave., NW, Washington, DC 20036; (202) 2328656.

18-2 1-Data Base: Lockheed/DIALOG: Files: PREDICASTS, INSPEC, ART, On-Line Bibliographic Systems, University of Pittsburgh Graduate School of Library and Information Sciences, Pennsylvania. Fee: $\$ 150$.

Contact: Professor Allen Kent, Room 801, Library and Information Sciences Building, University of Pittsburgh, PA 15260; (412) 6245218.

\section{July}

2-6-AACR 2: International workshop on AACR 2, Liverpool Polytechnic, Liverpool, England. Fee: $\$ 317$ (approx., includes five nights' accommodation).

Contact: Joan M. Bibby, Dept. of Lib. and Inform. Studies, Liverpool Polytechnic, Tithebarn St., Liverpool L2 2ER, UK.

2-14-Personnel Management: LRC: Personnel Management, summer school workshop, Appalachian State University, Boone, North Carolina.

Contact: Dr. D. Joleen Bock, Department of Educational Media, Appalachian State University, Boone, NC 28608.

9-13-Audiovisual: Audiovisual cataloging using AACR 2, Mankato State University, Mankato, Minnesota. Fee: $\$ 60$ non residents of $\mathbf{M i n -}$ nesota; $\$ 32$ residents.

Contact: Nancy B. Olson, Memorial Library, Mankato State University, Mankato, MN 56001: (507) 3896201

9-20-Networking: Institute on Library Networking in the Nationwide \& International Context, Catholic University of America, Washington, D.C. Fee: $\$ 235$.

Contact: Director of Continuing Education, The Catholic University of America, Washington, DC 20064.

9-August 3-Conservation: The conservation of research library materials, University of Illinois, Newberry Library, Chicago. Fee: $\$ 104$. Contact: Richard F. Casper, University of Illinois, Office of Continuing Education, $300 \mathrm{~W}$. Golf Rd., Mt. Prospect, IL 60056; (312) 2553320 . 
16-17-Audiovisual: Audiovisual cataloging using OCLC, Mankato State University, Mankato, Minnesota. Fee: $\$ 30$ nonresidents of Minnesota; $\$ 16$ residents.

Contact: Nancy B. Olson, Memorial Library, Mankato State University, Mankato, MN 56001; (507) 389-6201

20-22-Sherlock Holmes: Workshop on Sherlock Holmes, presented by John Bennett Shaw; Bradley University, Peoria, Illinois, and the Hansoms of John Clayton, the Sherlock Holmes Society of Peoria.

Contact: Barb Hoover, College of Continuing Education, Bradley University, Peoria, IL 61625.

23-August 17-Archives: Thirteenth Annual Archives Institute, Division of Librarianship, Emory University; Georgia Department of Archives and History; Atlanta, Georgia. Fees: $\$ 225$ noncredit; $\$ 624$ six quarter credit hours. Contact: Institute Coordinator, Georgia Department of Archives and History, 330 Capitol Ave., SE, Atlanta, GA 30334.

\section{BOOKS FREEZE-DRIED}

A flood damaged 40,000 books in the basement of the Meyer Library at Stanford University in November 1978. Now, to restore the books, Stanford and the Lockheed Corporation are employing a process similar to the one used in making freeze-dried food.

After the flood, Stanford librarians rushed the damaged books to the Modern Ice and Storage Co. in San Jose to be frozen before mold could form. In February the library began to truck batches of 4,000-5,000 books two times a week to the Lockheed Missiles and Space Company in Sunnyvale.

At Lockheed the books were placed in specially built racks inside a giant vacuum chamber once used to test the moon rover machine. The chamber was pumped down until the vacuum inside was equivalent to that found at an altitude of 200,000 feet. The books were then heated, and as they gradually thawed, the moisture was pulled from them because of the vacuum.

After two-and-one-half days of vacuum freezedrying at Lockheed, the books were trucked back to Palo Alto where they were rehumidified for three or four weeks.

After the books had regained some moisture from the normal atmosphere, Stanford staff were able to begin handling them safely, one by one, and to start the process of deciding whether to clean, repair, bind, reorder, or discard individual volumes.

Library Director David Weber hopes it will be possible to have most of the books back on the shelves before late September.

\section{UNIVERSITY LIBRARIAN UNIVERSITY OF CALIFORNIA, IRVINE}

The University of California, Irvine, is one of nine campuses of the University of California. The campus opened in 1965 and now has an enroliment of about 10,000 , and a faculty of over 600 , including the College of Medicine. The campus library system consists of a main library, five branches, a staff of 47 librarians, and 100 support personnel. The UCI Library, a component of the UC system containing more than 14 million volumes, is committed to a resource sharing plan and the application of new means of meeting the needs of the university community.

The University Librarian plans, organizes, directs, reviews, and evaluates all campus library functions; integrates library services with the instructional and research programs of the campus; and advises administrators in matters pertaining to library policy within the UC system. As a member of the Council of Deans, the University Librarian participates in discussions affecting the future of the campus. Within the library, a Council of Department Heads serves as the principal advisory body to the University Librarian.

Requirements of the position include: Broadly based competence in an academic/research library, demonstrated administrative experience at a multidivisional level, evidence of skill in providing leadership for a large professional and support staff, demonstrated understanding of the responsibilities of a library that meets the needs of those engaged in research and scholarly activities in a university, professional knowledge of national issues in librarianship and university education, and evidence of scholarly achievement. The minimum degree requirement is the MLS. Minimum salary: $\$ 30,900$.

Applications from interested candidates must be received by May 18, 1979. Submit resume to:

\section{Margot Parr, Employment Manager 152 Administration Building University of California, Irvine Irvine, California 92717}

AN AFFIRMATIVE ACTION

EMPLOYER - WOMEN, MINORITIES

HANDICAPPED PERSONS AND

VETERANS ARE ENCOURAGED TO $A P P L Y$ 


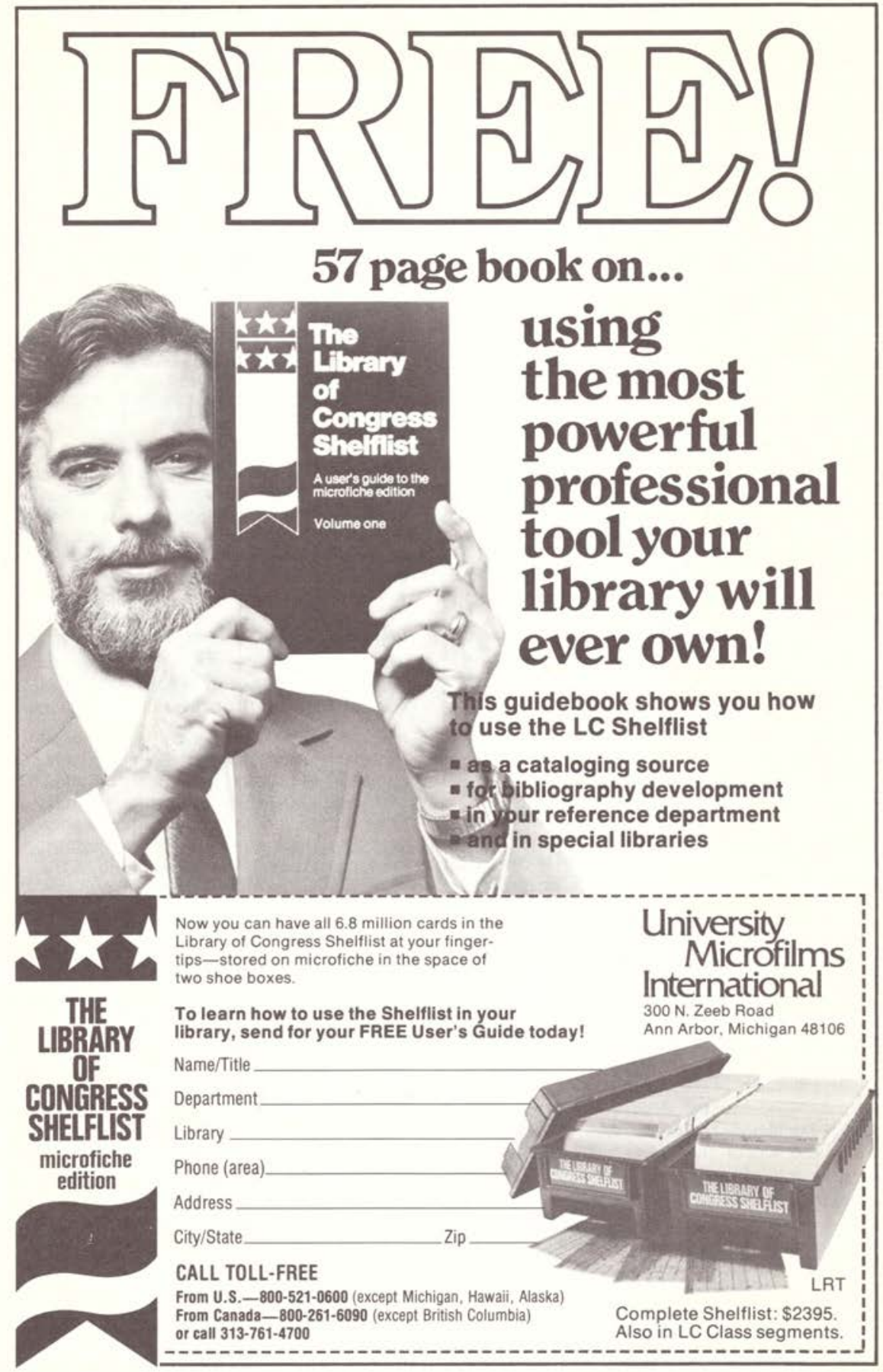

